\title{
Influence of the plasma nitriding conditions on the chemical and morphological characteristics of TiN coatings deposited on silicon
}

\author{
Influência das condições da nitretação a plasma nas características \\ químicas e morfológicas de recobrimentos de TiN depositados sobre silício \\ João Valério de Souza Neto1, Ricardo Silva de Freitas ${ }^{1}$, Bartolomeu Cruz Viana², Francisco Eroni Paz Santos², Pedro Augusto de \\ Paula Nascente ${ }^{3}$, Denise Aparecida Tallarico ${ }^{4}$, Valmor Roberto Mastelaro ${ }^{5}$, Rômulo Ribeiro Magalhães de Sousa²
}

\begin{abstract}
Titanium nitride (TiN) coatings were grown on silicon substrates by cathodic cage plasma deposition (CCPD). TiN coatings present interesting properties, such as high hardness, chemical and thermal stabilities, good thermal and electrical conductivities, and corrosion resistance, making them suitable for several technologically important applications. The influence of parameters such as plasma nitriding atmosphere, temperature, and time on the chemical and morphological characteristics of the deposited coatings was investigated by means of Raman spectroscopy, scanning electron microscopy, energy dispersive spectroscopy, and X-ray photoelectron spectroscopy. The results obtained by these characterization techniques revealed that the TiN coatings produced by CCPD presented high quality.
\end{abstract}

Keywords: Titanium nitride, Cathodic cage plasma deposition, Coatings.

\section{RESUMO}

Os recobrimentos de nitreto de titânio (TiN) foram crescidos sobre substratos de silício pela deposição por plasma em gaiola catódica (CCPD). Os recobrimentos de TiN apresentam propriedades interessantes, tais como alta dureza, estabilidades químicas e térmicas, boas condutividades térmicas e elétricas, e resistência à corrosão, fazendo com que eles sejam apropriados para várias aplicações tecnologicamente importantes. A influência de parâmetros como a atmosfera da nitretação por plasma, a temperatura e o tempo sobre as características químicas e morfológicas dos recobrimentos depositados foi investigada por meio de espectroscopia Raman, microscopia eletrônica de varredura, espectroscopia de energia dispersiva e espectroscopia de fotoelétrons excitados por raios $X$. Os resultados obtidos por essas técnicas de caracterização revelaram que os recobrimentos de TiN produzidos por CCPD apresentaram alta qualidade.

Palavras-chave: Nitreto de titânio, Deposição por plasma em gaiola catódica, Recobrimentos.

\footnotetext{
'Instituto Federal de Educação, Ciência e Tecnologia do Piauí - Programa de Pós-Graduação em Engenharia de Materiais - Teresina/PI - Brazil. Universidade Federal do Piauí - Departamento de Física - Teresina/PI - Brazil.

3Universidade Federal de São Carlos - Departamento de Engenharia de Materiais - São Carlos/SP - Brazil.

${ }^{4}$ Universidade Federal de São Carlos - Departamento de Engenharia de Produção - Sorocaba/SP - Brazil.

${ }^{5}$ Universidade de São Paulo - Instituto de Física de São Carlos - São Carlos/SP - Brazil.

Correspondence author: Pedro Augusto de Paula Nascente |Universidade Federal de São Carlos - Departamento de Engenharia de Materiais | Rod.

Washington Luis km 235 | CEP 13.565-905 - São Carlos/SP - Brazil | E-mail: nascente@ufscar.br

Received: Dec. 13, 2017| Approved: Apr. 6, 2018
} 


\section{INTRODUCTION}

The cathodic cage plasma deposition (CCPD) was developed by Alves et al. ${ }^{1}$ and has been employed for depositing a variety of coatings on different substrates ${ }^{1-9}$. In the CCPD process, the samples are inserted on an alumina insulator disk that is located inside a cage with uniformly distributed round holes of fixed diameter, so that the plasma acts on the cage and not on the sample surface, avoiding possible defects that are commonly formed during conventional plasma deposition ${ }^{1-9}$. The CCPD technique has been used for treating not only metallic materials but also electrical insulator materials ${ }^{1-4}$, and it produces coatings that have high uniformity. This technique allows for good control of roughness and crystallinity, and possesses versatility, simplicity, and low $\operatorname{cost}^{8}$. Sousa et al. ${ }^{8,9}$ have recently shown that this low-cost CCPD method can be effectively used for producing high quality $\mathrm{TiN}$ and $\mathrm{TiO}_{2}$ thin films.

The two stoichiometric phases found in the Ti-N phase diagram are $\delta$-TiN (face centered cubic structure) and $\varepsilon-\mathrm{Ti}_{2} \mathrm{~N}$ (tetragonal structure) phases ${ }^{10,11}$. Several researchers have concentrated in understanding the relationships between the deposition methods and the TiN phases produced, searching for the highest quality coatings. The desirable phase is $\delta$-TiN, since it has excellent properties such as high hardness ${ }^{12-14}$, chemical and thermal stabilities ${ }^{15}$, good thermal and electrical conductivities ${ }^{16}$, and corrosion resistance ${ }^{17}$, thus TiN coating can be employed for improving the lifetime of tools and components due to its ability of enhancing the surface hardness and decreasing the friction coefficient of the coated materials ${ }^{8,18}$. TiN coating is also used in integrated circuits, solar cells, transparent films, and photothermal conversion ${ }^{19}$.

Various deposition methods have been employed to deposit TiN coatings, such as dip-coating, sol-gel, thermal oxidation, e-beam, sputtering, chemical vapor deposition (CVD), plasma-enhanced CVD, metalorganic CVD, and molecular beam epitaxy ${ }^{14,20-30}$. Raman spectroscopy has been used to identify $\delta$-TiN phase in the deposited coatings since the acoustic and optical modes refer to Ti and $\mathrm{N}$ vibrations ${ }^{14,31-33}$. In this work, not only Raman spectroscopy but also scanning electron microscopy (SEM), energy dispersive spectroscopy (EDS), and X-ray photoelectron spectroscopy (XPS) are used to investigate the influence of the plasma nitriding conditions (atmosphere, temperature, and time) on the chemical and morphological characteristics of the TiN coatings deposited on silicon by CCPD.

\section{EXPERIMENT}

The depositions were performed using a conventional plasma reactor that had two concentric, cylindrical cathodic cages ${ }^{8}$. A DC electrical source was used with a maximum voltage of $1500 \mathrm{~V}$ and a maximum current of $2 \mathrm{~A}$. The cylindrical reactor was made of austenitic stainless steel, and had a diameter of $30 \mathrm{~cm}$ and a height of $40 \mathrm{~cm}$. Inside this reactor two concentric cathodic cages, made of grade 2 titanium perforated sheet $2.0 \mathrm{~mm}$ thick, were inserted. The external cage had a diameter of $77 \mathrm{~mm}$ and a height of $55 \mathrm{~mm}$, while the inner one had a diameter of $60 \mathrm{~mm}$ and a height of $50 \mathrm{~mm}$. Round holes $8 \mathrm{~mm}$ in diameter were uniformly punched on both cages with $9.2 \mathrm{~mm}$ of distance between the centers of adjacent holes. The samples were positioned equidistantly from the inner cage walls, onto an alumina disk having a diameter of $45 \mathrm{~mm}$ and a thickness of $3 \mathrm{~mm}$, for electrical insulation. The Si substrates had dimensions of $10 \mathrm{~mm} \times 8 \mathrm{~mm} \times 1 \mathrm{~mm}$ and were ultrasonically cleaned with acetone before plasma treatment. Figure 1 displays a schematic model of the reactor.

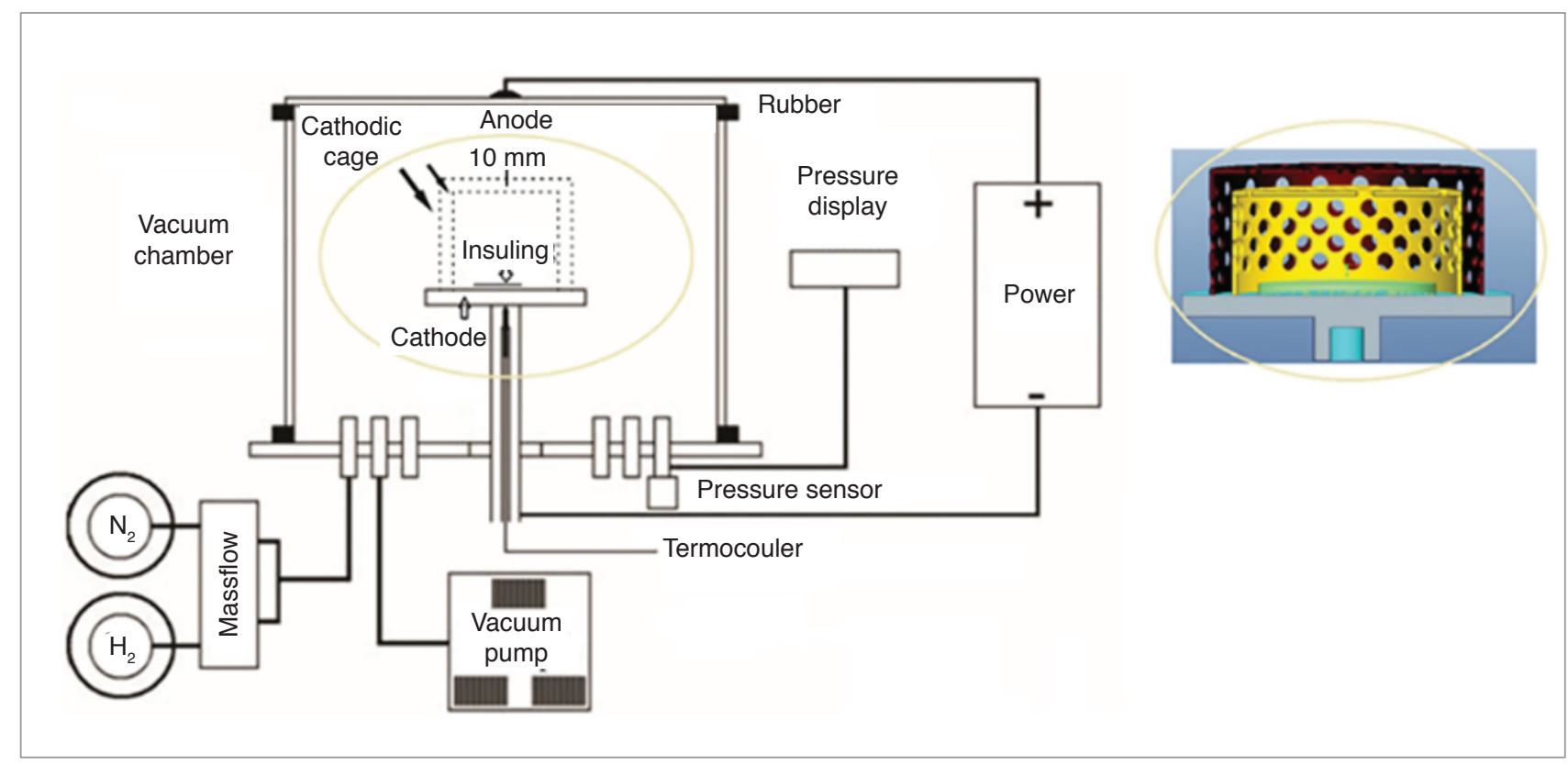

Figure 1: Schematic model of the double cathodic cage plasma reactor. 
Before plasma treatment, the cages were ground, polished, and ultrasonically etched in a solution of $50 \mathrm{ml}$ of $\mathrm{HNO}_{3}, 25 \mathrm{ml}$ of $\mathrm{HF}$, and $425 \mathrm{ml}$ of $\mathrm{H}_{2} \mathrm{O}$ for $10 \mathrm{~min}$, and then were rinsed with acetone and dried; and the reactor was cleaned with argon purging for $30 \mathrm{~min}$, followed by a pre-sputtering for also $30 \mathrm{~min}$. The plasma was applied on the cathodic cage, which played the role of the cathode, and the chamber wall was the anode, while the substrates were kept in a floating potential. Schematic models of the reactor are shown in Souza et al. ${ }^{8,9}$

Two gas mixtures were used as nitriding atmospheres: (a) $6 \mathrm{sccm} \mathrm{N} \mathrm{N}_{2}$ and $18 \mathrm{sccm} \mathrm{H}_{2}\left(25 \% \mathrm{~N}_{2}-75 \% \mathrm{H}_{2}\right)$ and (b) $18 \mathrm{sccm} \mathrm{N}$ and $6 \mathrm{sccm} \mathrm{H}_{2}\left(75 \% \mathrm{~N}_{2}-25 \% \mathrm{H}_{2}\right)$; two temperatures were applied to the substrates: 300 and $350{ }^{\circ} \mathrm{C}$; three treatment times were used for each temperature: 1, 2, and $4 \mathrm{~h}$; and the pressure was $150 \mathrm{~Pa}$. Table 1 summarizes the plasma nitriding conditions used for producing the 12 samples; $A$ refers to the $25 \% \mathrm{~N}_{2}-75 \% \mathrm{H}_{2}$ plasma atmosphere, and $B$ to the $75 \% \mathrm{~N}_{2}-25 \% \mathrm{H}_{2}$ plasma atmosphere.

Table 1: Summary of the plasma nitriding conditions used for producing the 12 samples.

\begin{tabular}{|c|c|c|c|}
\hline Atmosphere & $\begin{array}{c}\text { Temperature } \\
\left({ }^{\circ} \mathrm{C}\right)\end{array}$ & $\begin{array}{l}\text { Time } \\
\text { (h) }\end{array}$ & Sample \\
\hline \multirow{6}{*}{$25 \% \mathrm{~N}_{2}-75 \% \mathrm{H}_{2}$} & \multirow{3}{*}{300} & 1 & $\mathrm{~A} 1$ \\
\hline & & 2 & A2 \\
\hline & & 4 & A3 \\
\hline & \multirow{3}{*}{350} & 1 & A4 \\
\hline & & 2 & A5 \\
\hline & & 4 & A6 \\
\hline \multirow{6}{*}{$75 \% \mathrm{~N}_{2}-25 \% \mathrm{H}_{2}$} & \multirow{3}{*}{300} & 1 & B1 \\
\hline & & 2 & B2 \\
\hline & & 4 & B3 \\
\hline & \multirow{3}{*}{350} & 1 & B4 \\
\hline & & 2 & B5 \\
\hline & & 4 & B6 \\
\hline
\end{tabular}

Raman spectroscopy was performed using a monograting Bruker Senterra spectrometer equipped with a charge-coupled device (CCD) detection system and a $785 \mathrm{~nm}$ Perkin-Elmer solid state laser that yielded a power of $10 \mathrm{~mW}$ on the surface and a resolution of $3 \mathrm{~cm}^{1}$. An Olympus microscope lens with a magnification of $20 \times$ was used for focusing. The recording time was $10 \mathrm{~s}$ with 6 accumulations. The baseline subtraction was performed in each spectrum to compare the intensity ratios. SEM analyses were carried out using a Quanta 250 FEI microscope equipped with a field emission gun (FEG) in the following image modes: secondary electrons (SE) and backscattered electrons (BE). This microscope was coupled with an EDS spectrometer that operated at $20 \mathrm{kV}$, take-off angle of $55^{\circ}$, and working distance of approximately $17 \mathrm{~mm}$. SEM was employed to obtain the mean thicknesses of the deposited coatings by means of cross-section micrographs; six cross-section micrographs were taken for each sample, three using BE mode and other three using SE mode. XPS analyses were performed using a V Omicron Nanotechnology 1712-82-14 spectrometer, and the spectra were fitted using the CASA software package.

\section{RESULTS AND DISCUSSION}

Figures $2 \mathrm{a}$ and $2 \mathrm{~b}$ display the Raman spectra for the coatings deposited on silicon $25 \% \mathrm{~N}_{2}-75 \% \mathrm{H}_{2}$ (A1, A2, A3, A4, A5, and A6 samples), and Figs. 2c and $2 \mathrm{~d}$ for the coatings deposited on $75 \%$ $\mathrm{N}_{2}-25 \% \mathrm{H}_{2}$ atmospheres (B1, B2, B3, B4, B5, and B6 samples); Figs. $2 \mathrm{a}$ and $2 \mathrm{c}$ at $300{ }^{\circ} \mathrm{C}$, and Figs. $2 \mathrm{~b}$ and $2 \mathrm{~d}$ at $350{ }^{\circ} \mathrm{C}$ for 1,2 , and $4 \mathrm{~h}$. The Raman bands observed for all samples correspond to the transverse acoustic (TA), longitudinal acoustic (LA), and a combination of transverse optical (TO) and longitudinal optical (LO) TiN modes ${ }^{34,35}$. Cheng et al. ${ }^{35}$ have reported that scattering in the acoustic range (TA and LA modes) is associated to vibrations of the heavier Ti ions, while the scattering in the optical range (TO and LA) refers to vibrations of the lighter $\mathrm{N}$ ions. The stoichiometry of the $\mathrm{Ti}_{\mathrm{x}} \mathrm{N}$ compound is directly related to the positions and relative intensities of the acoustic and optical bands, and it is possible to extract the $\mathrm{N} /(\mathrm{N}+\mathrm{Ti})$ ratios by using a fitting software $^{33,35}$. The results for the coatings deposited on silicon at $25 \% \mathrm{~N}_{2}-75 \% \mathrm{H}_{2}$ are presented in Table 2. For comparison, the $\mathrm{N} /(\mathrm{N}+\mathrm{Ti})$ ratios obtained by both XPS and EDS are also shown.

The $\mathrm{N} /(\mathrm{N}+\mathrm{Ti})$ ratio obtained by Raman spectroscopy is close to stoichiometric $\delta$-TiN for the A1 sample, however, it was not possible to obtain an average EDS value. Figure 3 displays SEM micrographs obtained by $3 \mathrm{a} \mathrm{SE}$ and $3 \mathrm{~b}$ cross-section BE modes for the A1 sample, revealing that this coating is not evenly formed.

The $\mathrm{N} /(\mathrm{N}+\mathrm{Ti})$ ratios obtained by both Raman spectroscopy and EDS are close to each other for the coating deposited at $25 \% \mathrm{~N}_{2}-75 \% \mathrm{H}_{2}$ atmosphere at $300{ }^{\circ} \mathrm{C}$ for $2 \mathrm{~h}$ (A2 sample). Figure 4 displays cross-section SEM micrograph obtained using BE mode for the A2 sample, indicating the formation of a continuous bilayered coating with a diffusion layer, which has a thickness of approximately $2 \mu \mathrm{m}$ and is in contact with the Si substrate, followed by a $0.27-0.39 \mu \mathrm{m}$ thick outer layer. The mean thicknesses of the A1, A2, and A3 coatings are 0.129, 0.361, and $3.131 \mu \mathrm{m}$, respectively. It is observed that a longer treatment time yields the formation of a thicker coating. A similar behavior was reported by Nishimoto et al. ${ }^{36}$ for TiN layer deposited on steel by active screen plasma nitriding.

The A6 sample is the coating with more consistent $\mathrm{N} /(\mathrm{N}+\mathrm{Ti})$ ratio values, obtained by Raman spectroscopy, XPS, and EDS, being close to stoichiometric $\delta$-TiN. Figure 5 displays SEM micrographs obtained by $5 \mathrm{a}$ SE and $5 \mathrm{~b}$ cross-section $\mathrm{BE}$ modes for the A6 sample, revealing the formation of an even coating with a thickness of approximately $3 \mu \mathrm{m}$. This coating was formed in conditions not found in the literature, a gas mixture of $25 \% \mathrm{~N}_{2}-75 \% \mathrm{H}_{2}$ and a temperature $\left(350^{\circ} \mathrm{C}\right)$, considered low for coatings deposited by PVD. 

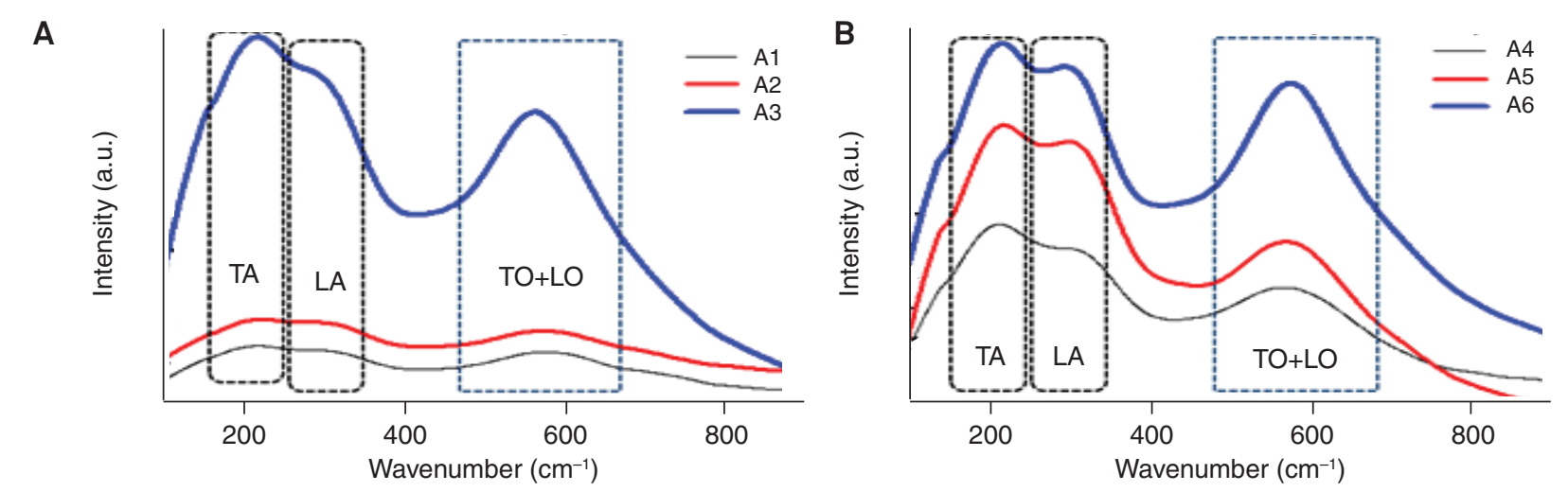

C
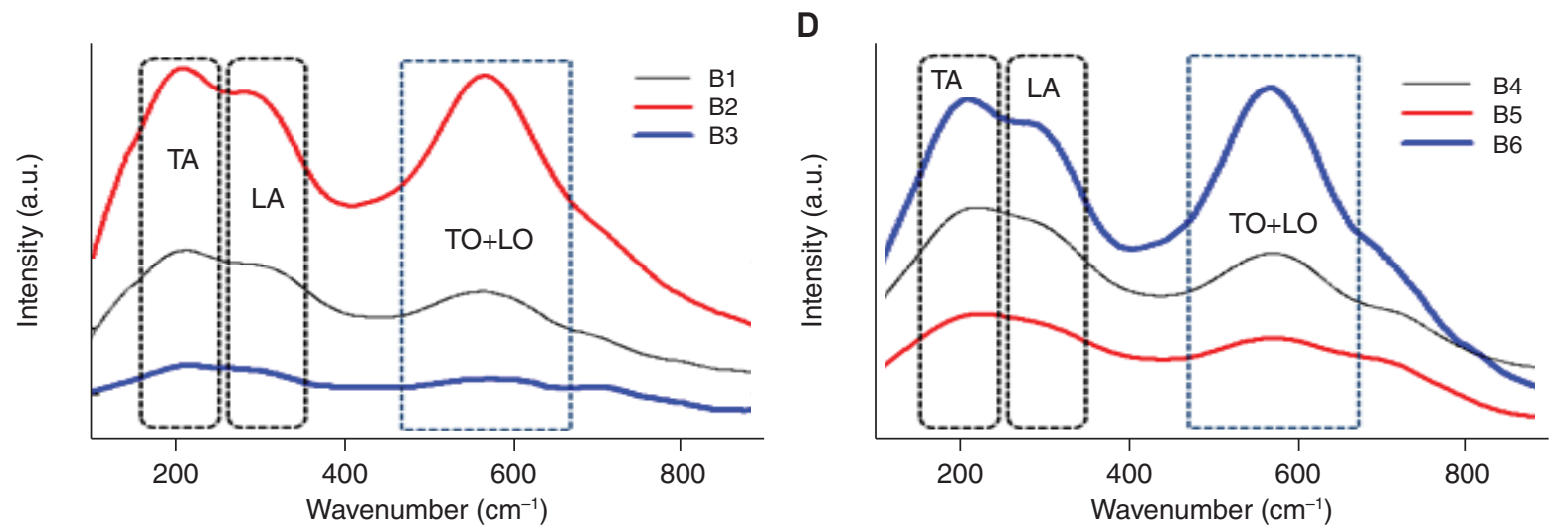

Figure 2: Raman spectra for the coatings deposited for 1, 2, and $4 \mathrm{~h}$ for: (A) $25 \% \mathrm{~N}_{2}-75 \% \mathrm{H}_{2}$ atmosphere at $300{ }^{\circ} \mathrm{C}$; (B) $25 \% \mathrm{~N}_{2}-75 \% \mathrm{H}_{2}$ atmosphere at $350{ }^{\circ} \mathrm{C}$; (C) $75 \% \mathrm{~N}_{2}-25 \% \mathrm{H}_{2}$ atmosphere at $300{ }^{\circ} \mathrm{C}$; and (D) $75 \% \mathrm{~N}_{2}-25 \% \mathrm{H}_{2}$ atmosphere at $350{ }^{\circ} \mathrm{C}$.

Table 2: $\mathrm{N} /(\mathrm{N}+\mathrm{Ti})$ ratios obtained by Raman spectroscopy, XPS and EDS.

\begin{tabular}{|c|c|c|c|}
\hline \multirow{2}{*}{ Sample } & \multicolumn{3}{|c|}{ N/(N + Ti) ratio } \\
\cline { 2 - 4 } & $\begin{array}{c}\text { Raman } \\
\text { spectroscopy }\end{array}$ & XPS & EDS \\
\hline A1 & 52 & 59 & - \\
\hline A2 & 40 & 48 & 41 \\
\hline A3 & 32 & 53 & 21 \\
\hline A4 & 26 & 55 & 32 \\
\hline A5 & 17 & - & 22 \\
A6 & 48 & 47 & 45 \\
B1 & 32 & 55 & 34 \\
B2 & 64 & 58 & 44 \\
B3 & 29 & 48 & - \\
B4 & 35 & 52 & 50 \\
B5 & 42 & 54 & 37 \\
B6 & 75 & 67 & 54 \\
\hline
\end{tabular}

The coating deposited at $75 \% \mathrm{~N}_{2}-25 \% \mathrm{H}_{2}$ atmosphere at $300^{\circ} \mathrm{C}$ for $1 \mathrm{~h}(\mathrm{~B} 1$ sample) has $\mathrm{N} /(\mathrm{N}+\mathrm{Ti})$ ratios which are close to each other, and could correspond to the $\varepsilon-\mathrm{Ti}_{2} \mathrm{~N}$ phase. Figure 6 displays SEM micrographs obtained by $6 \mathrm{a}$ SE and $6 \mathrm{~b}$ cross-section $\mathrm{BE}$ modes for the B1 sample, showing that the coating was unevenly formed.

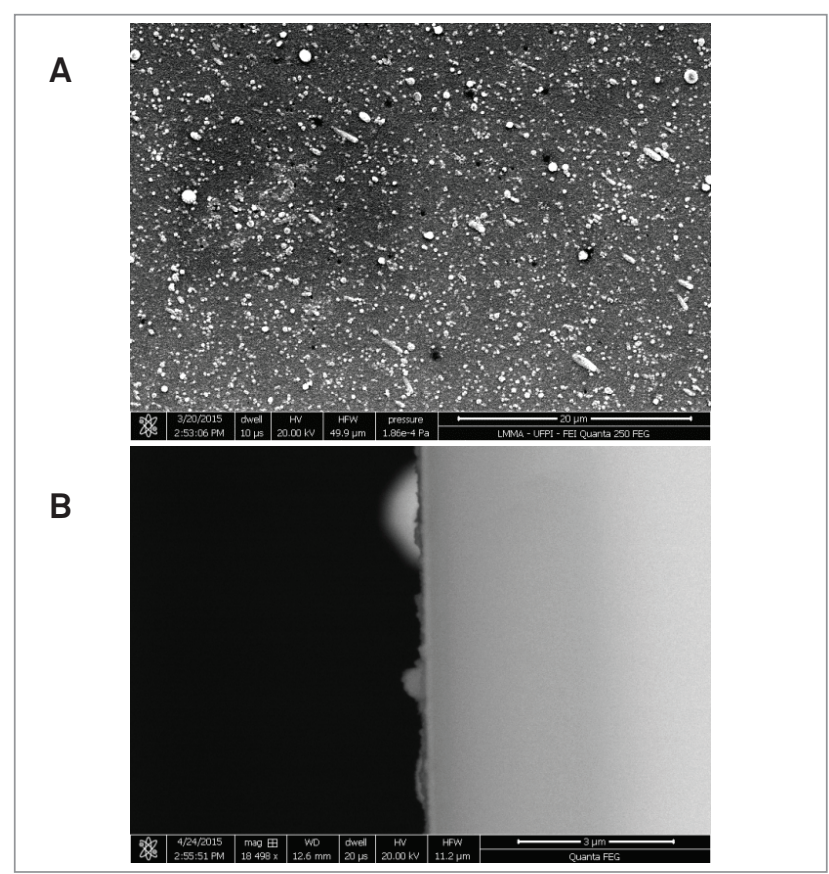

Figure 3: SEM micrographs obtained by (A) SE and (B) cross-section $\mathrm{BE}$ modes for the coating deposited under $25 \% \mathrm{~N}_{2}-75 \% \mathrm{H}_{2}$ atmosphere at $300^{\circ} \mathrm{C}$ for $1 \mathrm{~h}$ (A1 sample).

The $\mathrm{N} /(\mathrm{N}+\mathrm{Ti})$ ratios for the coating deposited at $75 \% \mathrm{~N}_{2}-25 \%$ $\mathrm{H}_{2}$ atmosphere at $300{ }^{\circ} \mathrm{C}$ for $2 \mathrm{~h}$ (B2 sample) are discrepant, but 


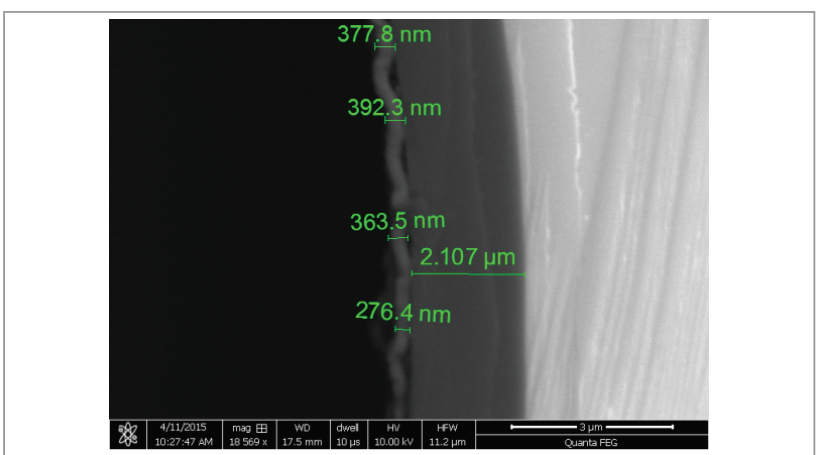

Figure 4: Cross-section SEM micrograph obtained by BE mode for the coating deposited at $25 \% \mathrm{~N}_{2}-75 \% \mathrm{H}_{2}$ atmosphere at $300{ }^{\circ} \mathrm{C}$ for $2 \mathrm{~h}$ (A2 sample). their average ratio $(0.54)$ would associate this coating to the $\delta$-TiN phase. Figure 7 displays SEM micrographs obtained by 7a SE and $7 \mathrm{~b}$ cross-section BE modes for the B2 sample, showing the formation of an even coating.

The coating deposited at $75 \% \mathrm{~N}_{2}-25 \% \mathrm{H}_{2}$ atmosphere at $300{ }^{\circ} \mathrm{C}$ for $4 \mathrm{~h}$ (B3 sample) has a low $\mathrm{N} /(\mathrm{N}+\mathrm{Ti})$ ratio obtained by Raman spectroscopy, but it was not possible to obtain an average EDS value. Figure 8 displays SEM micrographs obtained by $8 \mathrm{a}$ SE and $8 \mathrm{~b}$ cross-section $\mathrm{BE}$ modes for the $\mathrm{B} 3$ sample, showing that the coating was not properly formed.

Table 2 shows that both XPS and EDS N/(N + Ti) ratios for the coating deposited at $75 \% \mathrm{~N}_{2}-25 \% \mathrm{H}_{2}$ atmosphere at $350{ }^{\circ} \mathrm{C}$ for $1 \mathrm{~h}$ (B4 sample) correspond to the desirable $\delta$-TiN phase. Figure 9

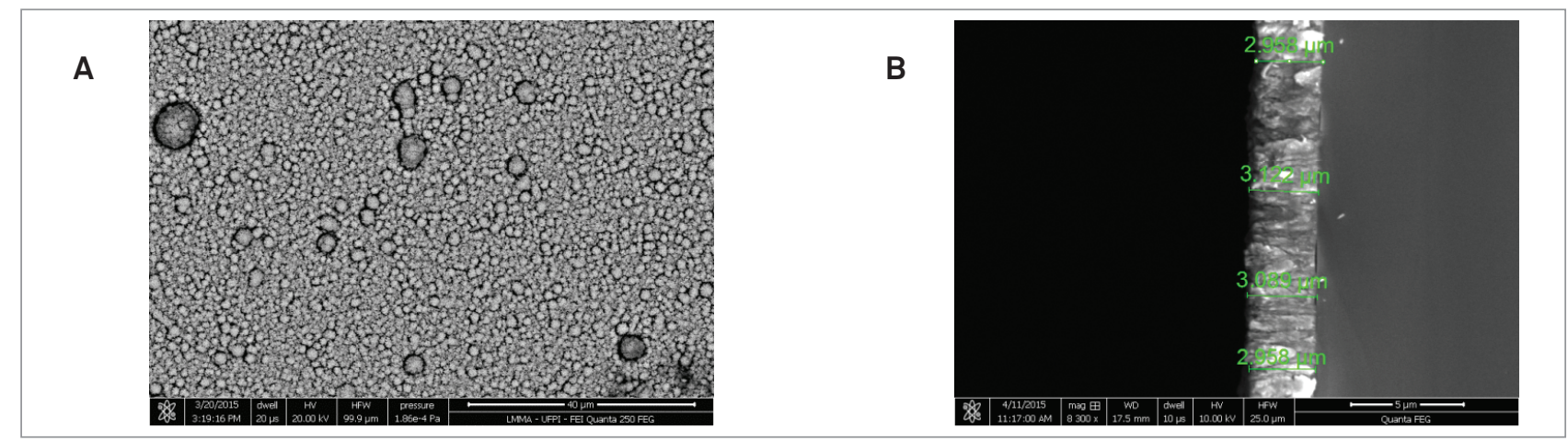

Figure 5: SEM micrographs obtained by (A) SE and (B) cross-section BE modes for the coating deposited at $25 \% \mathrm{~N}_{2}-75 \% \mathrm{H}_{2}$ atmosphere at $350^{\circ} \mathrm{C}$ for $4 \mathrm{~h}$ (A6 sample).

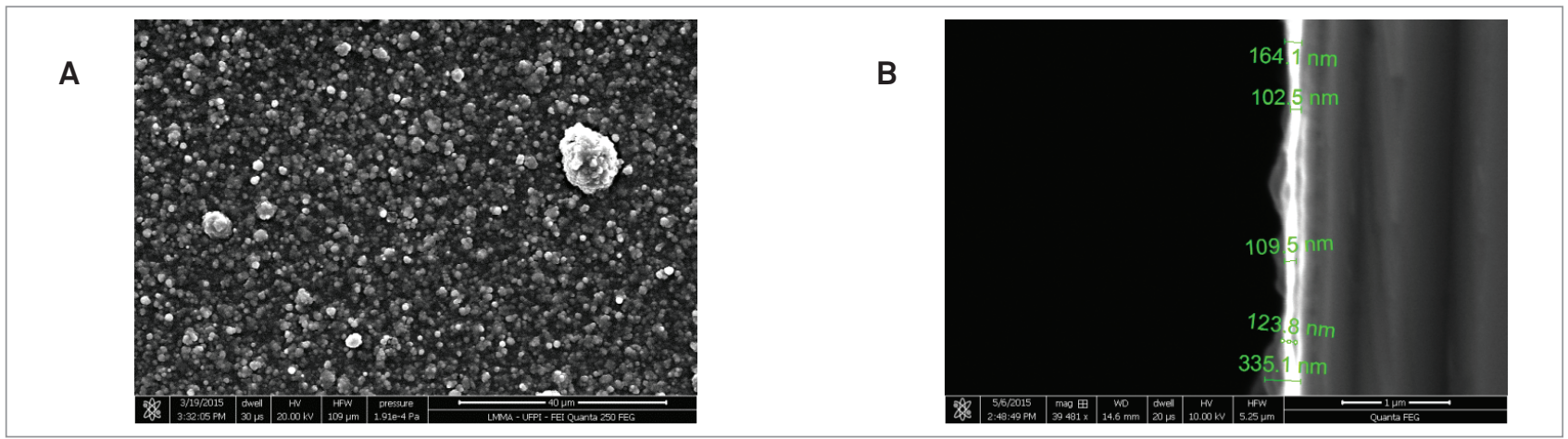

Figure 6: SEM micrographs obtained by (A) SE and (B) cross-section BE modes for the coating deposited at $75 \% \mathrm{~N}_{2}-25 \% \mathrm{H}_{2}$ atmosphere at $300{ }^{\circ} \mathrm{C}$ for $1 \mathrm{~h}$ (B1 sample).

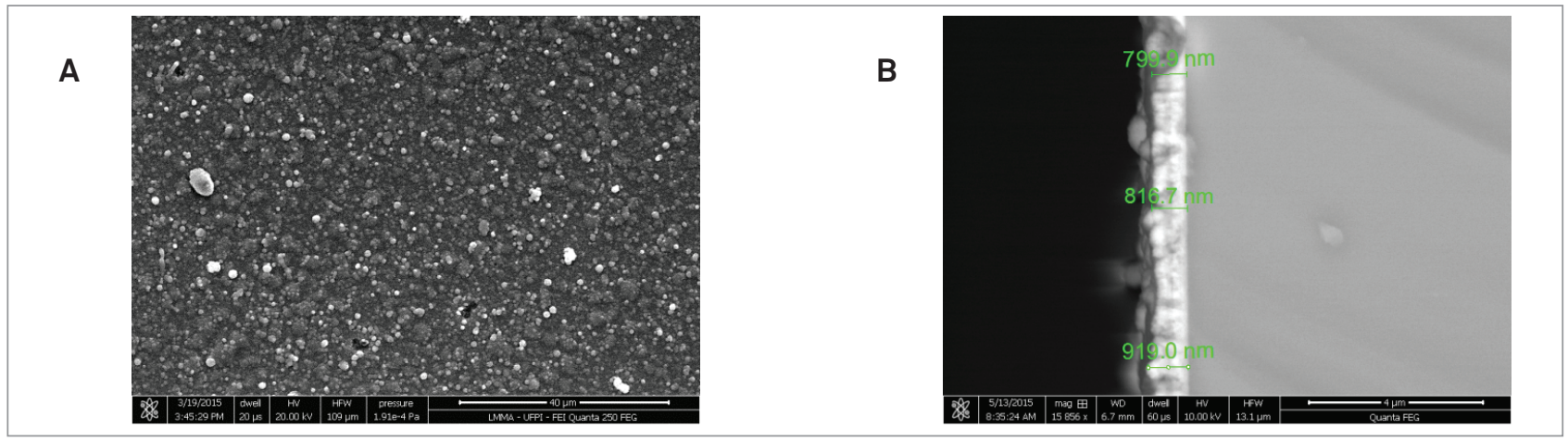

Figure 7: SEM micrographs obtained by (a) SE and (b) cross-section BE modes for the coating deposited at $75 \% \mathrm{~N}_{2}-25 \% \mathrm{H}_{2}$ atmosphere at $300{ }^{\circ} \mathrm{C}$ for $2 \mathrm{~h}$ (B2 sample). 
displays SEM micrographs obtained by $9 \mathrm{a}$ SE and 9b crosssection BE modes for the B4 sample, showing that the coating was evenly formed. The EDS quantitative result and SEM micrographs indicate that it is possible to deposit a coating within one hour of treatment using the CCPD technique, thus reducing processing time and cost.

$\mathrm{The} \mathrm{N} /(\mathrm{N}+\mathrm{Ti})$ ratios are relatively close to each other for the coating deposited at $75 \% \mathrm{~N}_{2}-25 \% \mathrm{H}_{2}$ atmosphere at $350{ }^{\circ} \mathrm{C}$ for $2 \mathrm{~h}$ (B5 sample), having values between those for the $\delta$ and $\varepsilon$ phases. Figure 10 displays SEM micrographs obtained by 10 a $\mathrm{SE}$ and $10 \mathrm{~b}$ cross-section $\mathrm{BE}$ modes for the $\mathrm{B} 5$ sample, showing an irregular morphology.

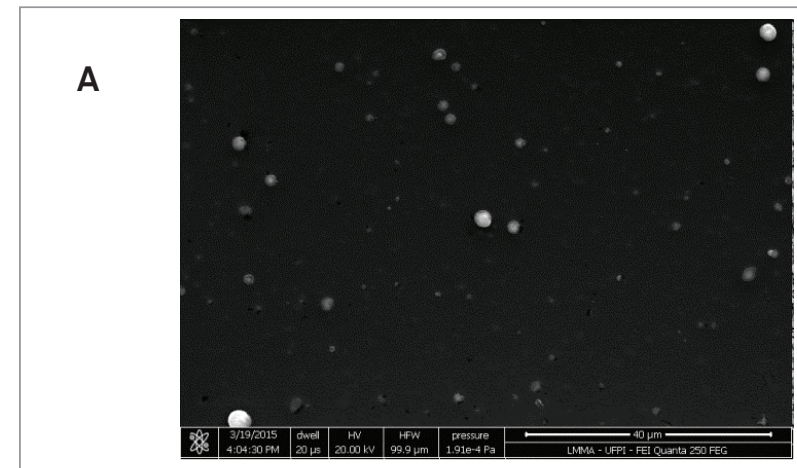

Table 2 shows that the $\mathrm{N} /(\mathrm{N}+\mathrm{Ti})$ ratio obtained by Raman spectroscopy for the coating deposited at 75\% $\mathrm{N}_{2}-25 \% \mathrm{H}_{2}$ atmosphere at $350{ }^{\circ} \mathrm{C}$ for $4 \mathrm{~h}$ (B6 sample) is considerably high, although the EDS ratio is close to stoichiometric $\delta$-TiN and the morphology of the coating is relatively even (Fig. 11).

The mean thicknesses of the B1, B2, B4, and B6 coatings are $0.122,0.853,0.622$, and $1.229 \mu \mathrm{m}$, respectively.

Among the 12 coatings that were produced by CCPD in this work, the one deposited at $25 \% \mathrm{~N}_{2}-75 \% \mathrm{H}_{2}$ atmosphere at $350{ }^{\circ} \mathrm{C}$ for $4 \mathrm{~h}$ (A6 sample) presents the best chemical and morphological characteristics, having a mean thickness of $3 \mu \mathrm{m}$. The coating

\section{B}

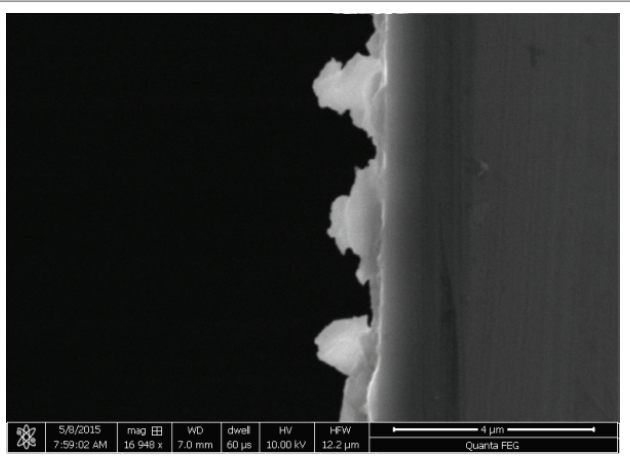

Figure 8: SEM micrographs obtained by (A) SE and (B) cross-section BE modes for the coating deposited at $75 \% \mathrm{~N}_{2}-25 \% \mathrm{H}_{2}$ atmosphere at $300{ }^{\circ} \mathrm{C}$ for $4 \mathrm{~h}$ (B3 sample).

A

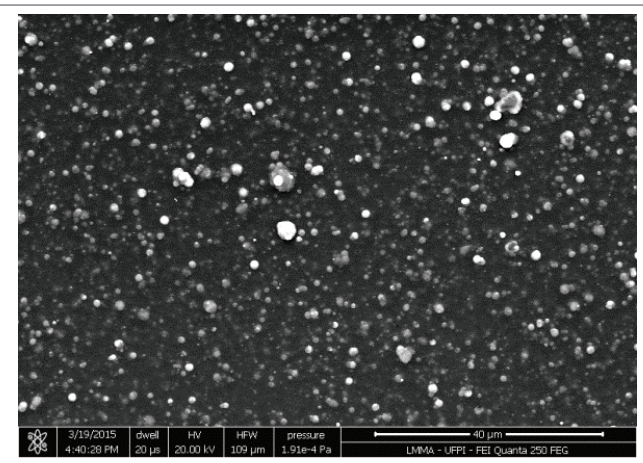

B

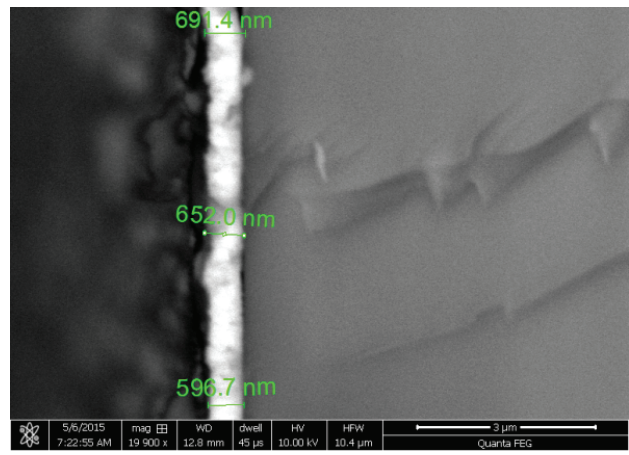

Figure 9: SEM micrographs obtained by (A) SE and (B) cross-section BE modes for the coating deposited at $75 \% \mathrm{~N}_{2}-25 \% \mathrm{H}_{2}$ atmosphere at $350^{\circ} \mathrm{C}$ for $1 \mathrm{~h}$ (B4 sample).



Figure 10: SEM micrographs obtained by (A) SE and (B) cross-section BE modes for the coating deposited at $75 \% \mathrm{~N}_{2}-25 \% \mathrm{H}_{2}$ atmosphere at $350{ }^{\circ} \mathrm{C}$ for $2 \mathrm{~h}$ (B5 sample). 




Figure 11: SEM micrographs obtained by (A) SE and (B) cross-section BE modes for the coating deposited at $75 \% \mathrm{~N}_{2}-25 \% \mathrm{H}_{2}$ atmosphere at $350{ }^{\circ} \mathrm{C}$ for $4 \mathrm{~h}$ (B6 sample).

deposited at the same temperature and for the same time, but at $75 \% \mathrm{~N}_{2}-25 \% \mathrm{H}_{2}$ atmosphere (B6 sample), also presents good chemical and morphological characteristics, with a mean thickness of $1 \mu \mathrm{m}$.

XPS survey and high energy resolution (Ti 2p, N 1s, O 1s, and C 1s) scans were acquired for all samples. The results of atomic ratios and binding energies are summarized in Tables 2 (alongside with the Raman spectroscopy and EDS values) and 3, respectively. In Table 3, the values in parentheses represent the relative intensity percentages of the peak components.

Figures 12, 13, and 14 display the $\mathrm{N} 1 \mathrm{~s}, \mathrm{O}$ 1s, and Ti 2p spectra, respectively, for the coating deposited at 25\% $\mathrm{N}_{2}-75 \% \mathrm{H}_{2}$ atmosphere at $300{ }^{\circ} \mathrm{C}$ for $4 \mathrm{~h}$ (A6 sample). The $\mathrm{N}$ 1s spectra can be fitted by four components. The A5 sample does not present either N1s nor Ti $2 p$ spectra. The most prominent one for all samples (except A4) has a binding energy in the range of $396.4-396.9 \mathrm{eV}$, and is associated to $\mathrm{TiN}^{37-41}$. The component at lower binding energy $(395.5-395.9 \mathrm{eV})$ can be attributed to $\mathrm{N}-\mathrm{C}^{41}$; the one at $398.2-398.8 \mathrm{eV}$, to $\mathrm{N}-\mathrm{O}\left(\mathrm{in}_{\mathrm{TiO}_{\mathrm{x}}} \mathrm{N}_{\mathrm{y}}\right)^{40,41}$; and the one that appears at higher binding energy for some samples could also be related to $\mathrm{N}-\mathrm{O}$ bonds in an oxynitride compound ${ }^{41}$.

The O 1s spectra can be fitted by four components (except for A5 sample). The most intense one presents a binding energy in the range of $529.5-530.0 \mathrm{eV}$, and is associated to $\mathrm{O}^{2-}$ in oxides; the

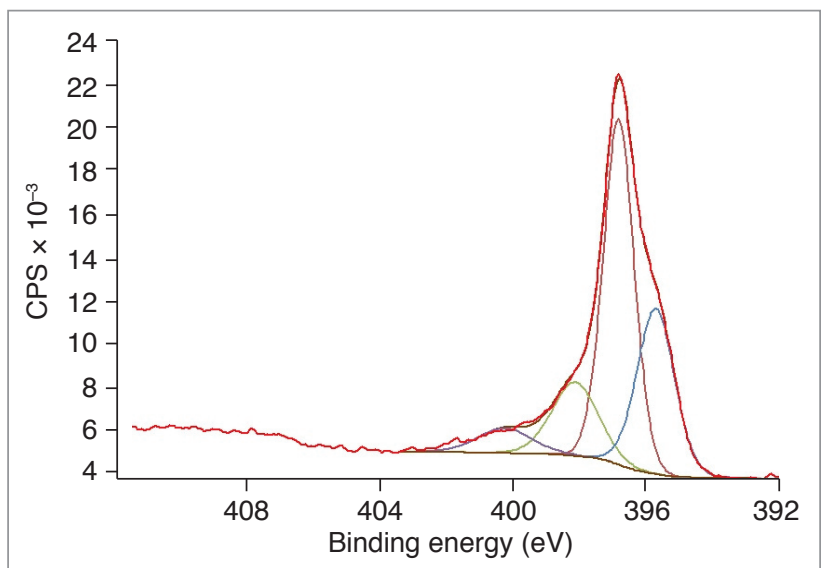

Figure 12: $\mathrm{N}$ 1s XPS spectrum for the coating deposited at $25 \%$ $\mathrm{N}_{2}-75 \% \mathrm{H}_{2}$ atmosphere at $300{ }^{\circ} \mathrm{C}$ for $4 \mathrm{~h}$ (A6 sample).
Table 3: Binding energies (in eV) obtained by XPS. The values in parentheses represent the relative intensity percentages of the peak components.

\begin{tabular}{|c|c|c|c|}
\hline Sample & Ti 2p3/2 & $\mathrm{N} 1 \mathrm{~s}$ & $01 \mathrm{~s}$ \\
\hline $\mathrm{A} 1$ & $\begin{array}{l}455.4(20) \\
456.7(24) \\
458.5(56)\end{array}$ & $\begin{array}{c}396.8(64) \\
398.5(10) \\
395.5(17) \\
400.2(9)\end{array}$ & $\begin{array}{c}529.7(34) \\
531.1(34) \\
532.5(25) \\
534.4(7)\end{array}$ \\
\hline A2 & $\begin{array}{l}455.4(24) \\
456.7(22) \\
458.5(54)\end{array}$ & $\begin{array}{l}396.8(51) \\
398.2(16) \\
395.7(22) \\
400.1(11)\end{array}$ & $\begin{array}{c}529.7(35) \\
531.1(34) \\
532.5(24) \\
534.4(7)\end{array}$ \\
\hline A3 & $\begin{array}{l}455.3(24) \\
456.6(22) \\
458.5(54)\end{array}$ & $\begin{array}{l}396.8(51) \\
398.2(17) \\
395.6(22) \\
400.3(10)\end{array}$ & $\begin{array}{c}529.8(34) \\
531.6(28) \\
532.6(9) \\
534.1(29)\end{array}$ \\
\hline A4 & $\begin{array}{l}455.3(14) \\
456.6(21) \\
458.5(65)\end{array}$ & $\begin{array}{l}396.6(32) \\
398.5(12) \\
395.5(21) \\
400.5(35)\end{array}$ & $\begin{array}{l}529.5(16) \\
531.4(17) \\
532.7(49) \\
534.4(18)\end{array}$ \\
\hline A5 & - & - & $\begin{array}{l}532.7(39) \\
534.1(61)\end{array}$ \\
\hline A6 & $\begin{array}{l}455.4(24) \\
456.7(22) \\
458.5(54)\end{array}$ & $\begin{array}{c}396.8(49) \\
398.1(16) \\
395.7(29) \\
400.2(6)\end{array}$ & $\begin{array}{c}529.7(44) \\
531.2(32) \\
532.7(19) \\
534.5(5)\end{array}$ \\
\hline B1 & $\begin{array}{l}455.5(25) \\
456.8(26) \\
458.5(49)\end{array}$ & $\begin{array}{l}396.8(49) \\
398.7(15) \\
395.8(26) \\
400.5(10)\end{array}$ & $\begin{array}{c}530.0(39) \\
531.5(32) \\
532.7(21) \\
534.2(8)\end{array}$ \\
\hline B2 & $\begin{array}{l}455.4(22) \\
456.7(24) \\
458.5(54)\end{array}$ & $\begin{array}{c}396.8(50) \\
398.3(16) \\
395.6(25) \\
400.2(9)\end{array}$ & $\begin{array}{c}530.0(36) \\
531.5(34) \\
532.8(24) \\
534.3(6)\end{array}$ \\
\hline B3 & $\begin{array}{c}455.4(6) \\
456.7(27) \\
458.5(67)\end{array}$ & $\begin{array}{l}396.8(23) \\
397.9(20) \\
395.9(42) \\
400.0(15)\end{array}$ & $\begin{array}{c}530.0(21) \\
531.5(34) \\
532.7(43) \\
534.2(2)\end{array}$ \\
\hline B4 & $\begin{array}{l}455.4(20) \\
456.8(27) \\
458.5(53)\end{array}$ & $\begin{array}{c}396.8(44) \\
398.1(21) \\
395.8(27) \\
400.5(8)\end{array}$ & $\begin{array}{l}529.9(32) \\
531.4(28) \\
532.6(24) \\
534.1(16)\end{array}$ \\
\hline B5 & $\begin{array}{l}455.4(21) \\
456.7(24) \\
458.5(55)\end{array}$ & $\begin{array}{c}396.8(54) \\
398.1(18) \\
395.6(22) \\
400.0(6)\end{array}$ & $\begin{array}{c}529.7(43) \\
531.2(34) \\
532.7(18) \\
534.4(5)\end{array}$ \\
\hline B6 & $\begin{array}{l}455.4(23) \\
456.6(26) \\
458.6(51)\end{array}$ & $\begin{array}{l}396.8(48) \\
398.0(14) \\
395.7(23) \\
400.0(15)\end{array}$ & $\begin{array}{c}530.0(41) \\
531.5(33) \\
532.7(22) \\
534.2(4)\end{array}$ \\
\hline
\end{tabular}




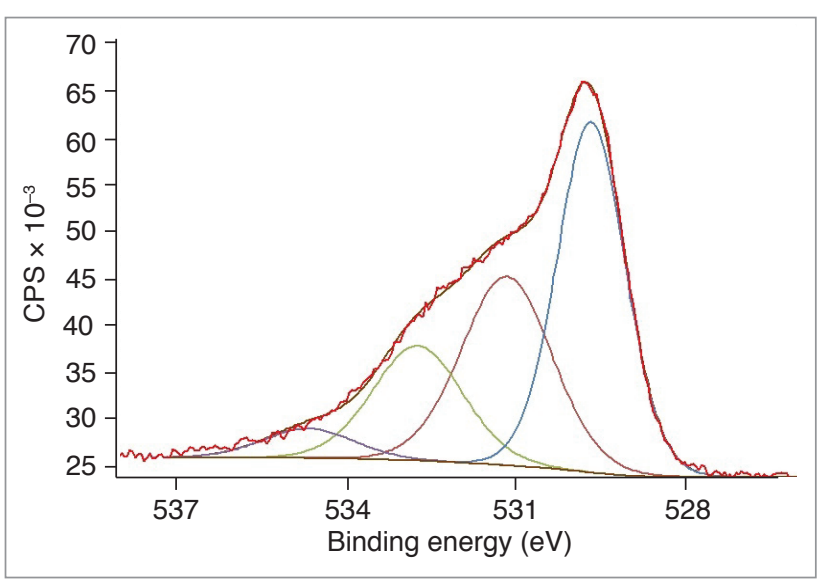

Figure 13: $\mathrm{O}$ 1s XPS spectrum for the coating deposited at 25\% $\mathrm{N}_{2}-75 \% \mathrm{H}_{2}$ atmosphere at $300^{\circ} \mathrm{C}$ for $4 \mathrm{~h}$ (A6 sample).



Figure 14: Ti 2p XPS spectrum for the coating deposited at 25\% $\mathrm{N}_{2}-75 \% \mathrm{H}_{2}$ atmosphere at $300^{\circ} \mathrm{C}$ for $4 \mathrm{~h}$ (A6 sample).

component at $531.1-531.6 \mathrm{eV}$ can be attributed to $\mathrm{N}-\mathrm{O}$ bonds in an oxynitride compound ${ }^{41}$; the one at $532.5-532.7 \mathrm{eV}$ is associated to $\mathrm{O}-\mathrm{C}$ from atmospheric contamination ${ }^{40}$; and the one at 534.1 - 534-5 eV can be related to adsorbed water and/or alcohols ${ }^{40}$.

The Ti $2 \mathrm{p}_{3 / 2}$ peaks can be fitted three components (Fig. 14). The component at $455.3-455.5 \mathrm{eV}$ is related to $\mathrm{TiN}^{37-41}$; the one at $456.6-456.8 \mathrm{eV}$, to $\mathrm{TiO}_{\mathrm{x}} \mathrm{N}_{\mathrm{y}}$; the one at $458.5-458.6 \mathrm{eV}$, to $\mathrm{TiO}_{2}^{40,41}$.

\section{CONCLUSIONS}

The CCPD technique was used for depositing TiN coatings on silicon substrates at $25 \% \mathrm{~N}_{2}-75 \% \mathrm{H}_{2}$ and $75 \% \mathrm{~N}_{2}-25 \% \mathrm{H}_{2}$ atmospheres, at 300 and $350{ }^{\circ} \mathrm{C}$, for 1,2 , and $4 \mathrm{~h}$ (total of 12 samples), and their chemical and morphological characteristics were analyzed by Raman spectroscopy, EDS, SEM, and XPS. The best quality coating was produced at $25 \% \mathrm{~N}_{2}-75 \% \mathrm{H}_{2}$ atmosphere at $350{ }^{\circ} \mathrm{C}$ for $4 \mathrm{~h}$ (A6 sample), and the second best, at the same temperature and same treatment time, at $75 \% \mathrm{~N}_{2}-25 \% \mathrm{H}_{2}$ atmosphere (B6 sample). The CCPD technique has proved to be effective in producing high quality coatings at lower temperatures and shorter treatment times as compared to other deposition techniques.

\section{ACKNOWLEDGMENTS}

The authors would like to thank Patrícia S. Sato for her assistance in part of the experiments. This work was partially supported by CNPq (process \#304555/2013-4).

\section{REFERENCES}

1. Alves Jr C, Araújo FO, Ribeiro KJB, Costa JAP, Sousa RRM, Sousa RS. Use of cathodic cage in plasma nitriding. Surf Coat Tech. 2006;201(6):2450. Available from: http://dx.doi. org/10.1016/j.surfcoat.2006.04.014

2. Sousa RMM, Araújo FO, Ribeiro KJB, Mendes MWD, Costa JAP, Alves Jr C. Cathodic cage nitriding of samples with different dimensions. Mat Sci Eng A 2007;465(1-2):223-227. Available from: http://dx.doi.org/10.1016/j.msea.2007.03.007

3. Sousa RRM, Araújo FO, Ribeiro KJB, Dumelow T, Costa JAP, Alves $\mathrm{Jr}$ C. Ionic nitriding in cathodic cage of AISI 420 martensitic stainless steel. Surf Eng. 2008;24(1):52-56. Available from: https://doi.org/10.1179/174329408X271589

4. Sousa RRM, Araújo FO, Barbosa JCP, Ribeiro KJB, Costa JAP, Alves Jr C. Nitriding using cathodic cage technique of austenitic stainless steel AISI 316 with addition of $\mathrm{CH} 4$. Mat Sci Eng A. 2008;487(1-2):124-127. Available from: https://doi. org/10.1016/j.msea.2007.10.001

5. Sousa RRM, Araújo FO, Costa JAP, Dumelow T, Oliveira RS, Alves Jr C. Nitriding in cathodic cage of stainless steel AISI 316: influence of sample position Vacuum. 2009;83(11):1402-1405. Available from: https://doi.org/10.1016/j.vacuum.2009.04.054

6. Sousa RRM, Araujo FO, Costa JAP, Oliveira AM, Melo MS, Alves Jr C. Cathodic cage nitriding of AISI 409 ferritic stainless steel with the addition of $\mathrm{CH} 4$. Mater Res. 2012;15(2):260-265. Available from: http://dx.doi.org/10.1590/S1516-14392012005000016

7. Sousa RRM, Araújo FO, Gontijo LC, Costa JAP, Alves Jr C. Cathodic cage plasma nitriding (CCPN) of austenitic stainless steel (AISI 316): influence of the different ratios of the (N2/H2) on the nitrided layers properties. Vacuum. 2012:86(12):2048-2053. Available from: https://doi.org/10.1016/j.vacuum.2012.05.008

8. Sousa RRM, Sato PS, Viana BC, Alves Jr C, Nishimoto A, Nascente PAP. Cathodic cage plasma deposition of $\mathrm{TiN}$ and $\mathrm{TiO} 2$ thin films on silicon substrates. J Vac Sci Technol A. 2015;33(4):041502. Available from: https://doi.org/10.1116/1.4919770

9. Sousa RRM, Araújo FO, Costa THC, Nascimento IO, Santos FEP, Alves $\mathrm{Jr} \mathrm{C}$, et al. Thin Tin and Tio2 film deposition in glass samples by cathodic cage. Mater Res. 2015;18(2):347-352. Available from: http://dx.doi.org/10.1590/1516-1439.313914

10. Molarius JM, Korhonen AS, Ristolainen EO. Ti-N phases formed by reactive ion plating. J Vac Sci Technol A. 1985;3(6):2419. Available from: https://doi.org/10.1116/1.572850

11. Bell T, Bergmann HW, Lanagan J, Morton PH, Staines AM. Surface engineering of titanium with nitrogen. Surf Eng. 1986;2(2):133-143. Available from: https://doi.org/10.1179/ sur.1986.2.2.133 
12. Sproul WD. Very high rate reactive sputtering of TiN, ZrN and HfN. Thin Solid Films. 1983;107(2):141-147. Available from: https://doi.org/10.1016/0040-6090(83)90016-0

13. Sproul WD, Rothstein R. High rate reactively sputtered TiN coatings on high speed steel drills. Thin Solid Films. 1985;126(34):257-263. Available from: https://doi.org/10.1016/00406090(85)90319-0

14. Constable CP, Yarwood J, Münz W-D. Raman microscopic studies of PVD hard coatings. Surf Coat Technol. 1999;116119:155-159. Available from: https://doi.org/10.1016/S02578972(99)00072-9

15. Hultman L. Thermal stability of nitride thin films. Vacuum. 2000:57(1):1-30. Available from: https://doi.org/10.1016/S0042207X(00)00143-3

16. Meng LJ, Azevedo A, Santos MP. Deposition and properties of titanium nitride films produced by dc reactive magnetron sputtering. Vacuum. 1995;46(3):233-239. Available from: https://doi.org/10.1016/0042-207X(94)00052-2

17. Panjan P, Navinšek B, Cvelbar A, Zalar A, Milošev I. Oxidation of TiN, ZrN, TiZrN, CrN, TiCrN and TiN/CrN multilayer hard coatings reactively sputtered at low temperature. Thin Solid Films. 1996:281-282:298-301. Available from: https://doi. org/10.1016/0040-6090(96)08663-4

18. Arias DF, Arango YC, Devia A. Study of TiN and $\mathrm{ZrN}$ thin films grown by cathodic arc technique. Appl Surf Sci. 2006;253:1683. Available from: https://doi.org/10.1016/j.apsusc.2006.03.017

19. Zhang YJ, Yan PX, Wu ZG, Xu JW, Zhang WW, Li X. Preparation and characterization of high-quality TiN films at low temperature by filtered cathode arc plasma. J Vac Sci Technol A. 2004;22(6):2419. Available from: https://doi. org/10.1116/1.1807836

20. Sproul WD, Rothstein R. High rate reactively sputtered TiN coatings on high speed steel drills. Thin Solid Films. 1985;126(34):257-263. Available from: https://doi.org/10.1016/00406090(85)90319-0

21. Hilton MR, Vandentop GJ, Salmeron M, Somorjai GA. TiN coatings on M2 steel produced by plasma-assisted chemical vapor deposition. Thin Solid Films. 1987:154(1-2):377-386. Available from: https://doi.org/10.1016/0040-6090(87)90380-4

22. Richter F, Kupfer H, Giegengack H, Schaarschmidt G, Scholze F, Elstner F. Fundamental mechanisms of titanium nitride formation by d.c. magnetron sputtering. In: Satwell BD, McGuire GE, Hofmann S. Metallurgical Coatings and Thin Films. Amsterdam: Elsevier; 1992. Available from: https://doi.org/10.1016/B978-0444-89900-2.50061-0

23. Chatterjee S, Chandrashekhar S, Sudarshan TS. Deposition processes and metal cutting applications of TiN coatings. J Mater Sci. 1992;27(13):3409-3423. Available from: https://doi. org/10.1007/BF01151815

24. Rebenne HE, Bhat DG. Review of CVD TiN coatings for wearresistant applications: deposition processes, properties and performance. Surf Coat Tech. 1994;63(1-2):1-13. Available from: https://doi.org/10.1016/S0257-8972(05)80002-7

25. Meng LJ, Azevedo A, Santos MP. Deposition and properties of titanium nitride films produced by dc reactive magnetron sputtering. Vacuum. 1995:46(3):233-239. Available from: https://doi.org/10.1016/0042-207X(94)00052-2

26. Rigato V, Maggioni G, Patelli A, Antoni V, Serianni G, Spolaore $M$, et al. Effects of plasma non-homogeneity on the physical properties of sputtered thin films. Surf Coat Tech. 2001:142144:943-949. Available from: https://doi.org/10.1016/S02578972(01)01258-0
27. Vaz F, Cerqueira P, Rebouta L, Nascimento SMC, Alves E, Goudeau PH, et al. Structural, optical and mechanical properties of coloured TiNxOy thin films. Thin Solid Films. 2004;447-448:449-454. Available from: https://doi. org/10.1016/S0040-6090(03)01123-4

28. Muratore C, Walton SG, Leonhardt D, Fernsler RF. Control of plasma flux composition incident on TiN films during reactive magnetron sputtering and the effect on film microstructure. $J$ Vac Sci Technol A. 2006;24(1):25. Available from: https://doi. org/10.1116/1.2134706

29. Nishimoto A, Bell TE, Bell T. Feasibility study of active screen plasma nitriding of titanium alloy. Surf Eng. 2010;26(1 2):74-79. Available from: https://doi.org/10.1179/02670840 9X12454193831760

30. Samal N, Du H, Luberoff R, Chetry K, Bubber R, Hayes A, et al. Low-temperature $\left(\leq 200^{\circ} \mathrm{C}\right)$ plasma enhanced atomic layer deposition of dense titanium nitride thin films. J Vac Sci Technol A. 2013;31(1):01A137. Available from: https://doi. org/10.1116/1.4769204

31. Chowdhury R, Vispute RD, Jagannadham K, Narayan J. Characteristics of titanium nitride films grown by pulsed laser deposition. J Mater Res. 1996:11(6):1458-1469. Available from: https://doi.org/10.1557/JMR.1996.0182

32. Zhang WH, Hsieh JH. Tribological behavior of TiN and $\mathrm{CrN}$ coatings sliding against an epoxy molding compound. Surf Coat Technol. 2000;130(1-2):240-247. Available from: https:// doi.org/10.1016/S0257-8972(00)00709-X

33. Vasconcellos MAZ, Hinrichs R, Javorsky CS, Giuriatt G, Borges da Costa JAT. Micro-Raman characterization of plasma nitrided Ti6Al4V-ELI. Surf Coat Technol. 2007;202(2):275-279. Available from: https://doi. org/10.1016/j.surfcoat.2007.05.038

34. Spengler W, Kaiser R. First and second order Raman scattering in transition metal compounds. Solid State Commun. 1976;18(7):881-884. Available from: https://doi. org/10.1016/0038-1098(76)90228-3

35. Cheng YH, Tay BK, Lau SP, Kupfer H, Richter F. Substrate bias dependence of Raman spectra for TiN films deposited by filtered cathodic vacuum arc. J Appl Phys. 2002;92(4):1845. Available from: https://doi.org/10.1063/1.1491588

36. Nishimoto A, Nii H, Narita R, Akamatsu K. Simultaneous duplex process of TiN coating and nitriding by active screen plasma nitriding. Surf Coat Technol. 2013;228(1) S558-S562. Available from: https://doi.org/10.1016/j. surfcoat.2012.04.021

37. Hieu NV. Lichtman D. X-ray photoelectron analysis of thin film Tinx. Appl Surf Sci. 1984;20(1-2):186-192. Available from: https://doi.org/10.1016/0378-5963(84)90338-6

38. Burrow BJ, Morgan AE, Ellwanger RC. A correlation of Auger electron spectroscopy, x-ray photoelectron spectroscopy, and Rutherford backscattering spectrometry measurements on sputter-deposited titanium nitride thin films. J Vac Sci Technol A. 1986;4(6):2463. Available from: https://doi. org/10.1116/1.574092

39. Hofmann S. Characterization of nitride coatings by Auger electron spectroscopy and $\mathrm{x}$-ray photoelectron spectroscopy. J Vac Sci Technol A. 1986;4(6):2789. Available from: https:// doi.org/10.1116/1.573680

40. Halbritter J, Leiste H, Mathes HJ, Walk P. ARXPS - Studies of nucleation and make-up of sputtered TiN-layers. Fresenius' $J$ Anal Chem. 1991;341(5-6):320-342. Available from: https:// doi.org/10.1007/BF00321927 
41. Jouan PY, Peignon $\mathrm{MC}$, Cardinaud $\mathrm{CH}$, Lempérière $\mathrm{G}$. Characterisation of TiN coatings and of the TiN/Si interface by X-ray photoelectron spectroscopy and Auger electron spectroscopy. Appl Surf Sci. 1993;68(4):595-603. Available from: https://doi.org/10.1016/0169-4332(93)90241-3

42. Ernsberger C, Nickerson J, Miller AE, Moulder J. Angular resolved X-ray photoelectron spectroscopy study of reactively sputtered titanium nitride. J Vac Sci Technol A. 1985;3(6):2415. Available from: https://doi.org/10.1116/1.572849

43. Prieto P, Kirby RE. X-ray photoelectron spectroscopy study of the difference between reactively evaporated and direct sputter-deposited TiN films and their oxidation properties. J Vac Sci Technol A. 1995;13(6):2819. Available from: https://doi. org/10.1116/1.579711 